\title{
ENSAIO SOBRE A LOUCURA:
}

Fábio Luiz de Arruda Herrig ${ }^{1}$

Confortável, pelo prazer de estar acomodado no objeto pelo que desenvolvera uma estima peculiar, refletia. Fobia considerava que a existência humana não é fruto de um contrato social. Tal termo apenas foi postulado por conta de que outro era um tanto quanto nauseante. Indignava-se pela dificuldade de poder gozar da presença da ausência, da sonoridade do silêncio. Nada lhe causava mais deleite do que a reflexão, a imaginação e a leitura. Desejava ser tragado pelas profundezas do espírito e abandonar qualquer vestígio de uma existência material.

No presente instante está envolto pelas dúvidas que acompanham a existência humana desde que os polegares opositores permitiram o desenvolvimento do cérebro dos homo: a morte é o fim ou a passagem?

Tais pensamentos apenas o tangiam pela angustia que o corroia. Ansiava por afastar-se das pessoas, mas por mais que se demonstrasse áspero e rude, sempre alguém buscava seus conhecimentos, seus auxílios ou simplesmente alguém com quem conversar.

Irônica se apresentava a existência dele. Por mais que buscasse isolar-se não o conseguia. Fobia sabia que tudo é formado a partir da cultura e tinha plena consciência de que se tivesse sido atendido em suas ânsias atuais nem se quer se teria tornado um si, seria apenas um amontoado orgânico que não teria a mínima serventia. Além disso, teve acesso a experiências semelhantes a sua, como a de um tal Lobo da Estepe, um ser ávido de solidão, porém frustrado, pois alguém tinha que lhe vender o vinho, lhe postar os livros, alugar o quarto, questionar sua singularidade, etc.

Até que um dia, tocado pelo espírito da genialidade humana, começou a observar uma espécie de marginal que, de maneira paulatina, principiou a aflorar uma certa atração em nosso personagem: o louco.

Com essa atração peculiar, começou a se recordar de algumas passagens. Lembrou de uma viagem que fez a Macondo, onde se encontrou com um cigano chamado Melquíades. Era um gênio. Dedicava sua vida ao estudo da alquimia, mas

\footnotetext{
${ }^{1}$ Mestrando em Letras pela Universidade Federal da Grande Dourados - UFGD, Faculdade de Comunicação, Artes e Letras - FACALE; graduado em História pela Universidade Estadual de Mato Grosso do Sul - UEMS. Email: karaiarruda@gmail.com
} 
devido à singularidade de suas pesquisas e à lentidão dos resultados, foi considerado louco e afastado do convívio dos seres normais.

Lembrou-se também de um tratado, escrito por Charles Darwin, no século XIX, que deveria integrar A Origem das Espécies, mas que de última hora foi retirado da prensa por conta de ser um assunto tão marginal que não merecia ser posto ao lado de estudos primorosos como os que ali se encontravam.

Dessa maneira, deu-se conta que a loucura era um artifício digno de louvores. Nada pode dar mais liberdade a um ser do que a loucura. O que seria de um Quixote se não pudesse ser louco? A maior sobriedade que existe está no louco. Jamais poderíamos ver uma sentença como esta que se segue se não da boca de um louco: "por la liberdad así como por la honra se puede y debe aventurar la vida".

Mas o fato é que diante dessas sentenças, Fobia fez estudos do que se considera estranho a um conjunto maior da sociedade e começou a agir conforme os resultados de suas pesquisas o instruíram até que o internaram num asilo para loucos. Porém, não pense o leitor que ele não fez importantes constatações antes de assumir esta postura, visto que a história dos hospícios e manicômios não são tangidas por contos de fadas. Certificou-se de que seria enviado a um local onde pudesse exercer sua loucura a sós e em paz.

E nesse instante, nas regiões abissais de seu ser, estava contente por sua solidão e por sua sentença que reajustava uma palavra, que a muito se havia deslocado, ao seu devido lugar: Hipocrisia social. 